\title{
РОЗШИРЕННЯ ТЕХНОЛОГІЧНИХ МОЖЛИВОСТЕЙ СТАНІВ ХПТР 15-30
}

На ринку споживання трубної продукції особливе місце займають холоднокатані труби спеціального призначення, які є найточнішою і високоякісною продукцією трубного виробництва. Забезпечення підвищених вимог до точності розмірів є однією з найважливіших задач при організації виробництва цих труб, в першу чергу призначених для використання в машинобудуванні і установках відповідального призначення. Найчастіше ці вимоги знаходяться на рівні нормативів прецизійного машинобудування, що пред'являються до циліндричних деталей, які виготовляються шляхом механічної обробки. Зростаючі вимоги до геометричних параметрів труб, їх міцності, жароміцності і стійкості до дії агресивних середовищ (в тому числі і опір проникаючої радіації високих рівнів), необхідності виготовлення тонкостінних і особливо тонкостінних труб призвело на початку 60 -х років до виникнення такого напрямку холодної пілігрімової прокатки, як спосіб холодної прокатки труб роликами (ХПТР). Стани для реалізації цього способу були розроблені у ВНДІМЕТМАШі і виготовлялися переважно на Алма-Атинському заводі важкого машинобудування (АЗТМ). Повторюючи основні технологічні і конструктивні рішення способу й устаткування валкової холодної пілігрімової прокатки, на станах ХПТР кінематично реалізована можливість значного спрощення робочого інструмента, що забезпечило можливість виготовляти труби зі стінкою до 0,1 мм і менше. Однак при цьому профіль рівчака, утворений роликами, обмежує абсолютну деформацію по діаметру (до 2.0 ... 2,5 мм) і робочий хід кліті використовується всього лише на $60 \%$ його довжини, що обумовлює малу продуктивність станів ХПТР (не перевищує $10 \ldots 20$ м / год.). Подальше вдосконалення у вигляді використання дворядного сепаратора дозволило збільшити деформацію по діаметру до 3 ... 3,5 мм 3 підвищенням точності і майже дворазовим підвищенням продуктивності. Такі показники були прийнятні при вирішенні завдань, що виникають в надрах військово-промислового комплексу, де собівартість продукції не була визначальним фактором існування технології. Питання продуктивності та номенклатурної широти продукції вирішувалися кількістю агрегатів, що встановлюються в трубоволочильний цехах.

Мета роботи. Еволюційний розвиток холодної пільгерної прокатки ставить завдання створення станів нового покоління, що відрізняються як підвищеною надійністю і продуктивністю щодо станів попередніх поколінь, так і розширенням технологічних можливостей експлуатованих. Досягнення цих результатів здійснюється шляхом реалізації на станах нового покоління ряду рішень: перехід від групового приводу до багатодвигунових (багатодвигунний привід включає в себе головний привід; приводи подачі заготовки в осередок деформації; повороту системи «заготовка - оправлення - готова труба»); здійснення неперервного процесу прокатки (подача трубної заготовки на лінію прокатки без зупинки процесу прокатки); розширення спектра технологічних режимів роботи стана; безступінчасте регулювання величин подачі і кутів повороту в процесі прокатки. Розробки нових систем електроприводу і автоматики [1-4] сприяють реалізації цих рішень не тільки при створенні станів нових поколінь, а й модернізації існуючих.

Розширення технологічних можливостей станів холодної прокатки труб роликами реалізується установкою в лінії головного приводу замість роликової валкової кліті і заміною циліндричної оправки конічною. Використовуваний на станах ХПТР поворотньо-подаючий комплекс (ППК) з мальтійським хрестом, забезпечуючий більш високий рівень точності подач, ніж кулачково-важільний ППК з механізмами вільного ходу, в той же час сприяє швидкому зносу калібрів і зниженню якісних показників готової продукції. В якості можливого альтернативного рішення доцільно реалізувати перехід від групового до багатодвигунових, наділивши систему управління розширеним спектром можливостей. 
На рис. 1 представлені різні конструктивні рішення валкових клітей для станів ХПТР 15-30.

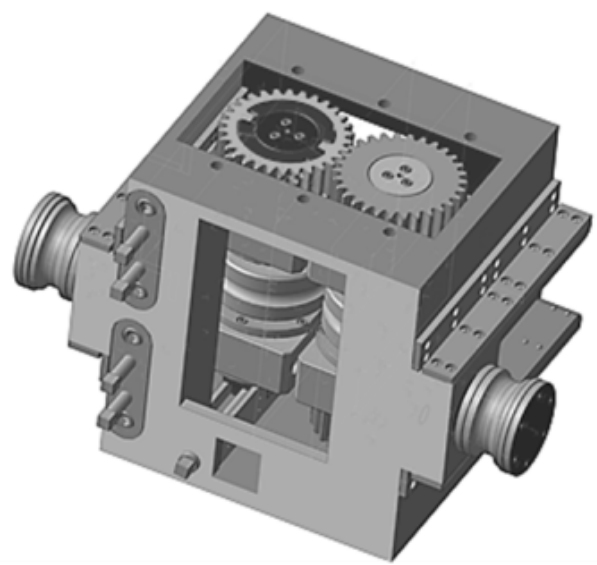

a

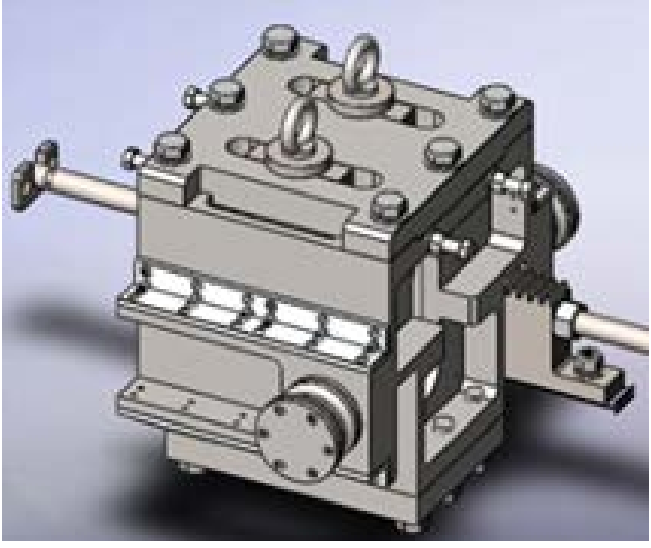

б

Рис. 1. Валкові кліті для стану ХПТР 15-30:

a - 3 вертикально орієнтованими валками конструкції ДТП (ВНДТІ); б - 3 горизонтально орієнтованими валками конструкція ТОВ «НВФ«СХІД ПЛЮС»

В умовах СМВО (м. Суми, Україна), яке спеціалізується на виготовленні машинобудівної продукції, що містить теплообмінники, були виконані дослідження холоднопільгерного процесу на стані ХПТР 15-30, обладнаного валковою кліттю, представленою на рис. 1, в , з заготовок діаметром 25 мм виготовлялись труби діаметрами 16 ... 12 мм. На рис. 2 в і 2 представлені типові картини вертикальних складових впливу на оброблювані вироби (на рис. 2. в їх повне значення; на рис. 2, 2- розподілене по опорах). 3 аналізу картини, представленої на рис. 2. г, видно, що ліві і праві (по ходу прокатки) підшипникові вузли сприймають вплив інструмента (полукалібрів валків) по-різному. Хоча картини навантаження конгруентні, співвідношення значень модулів реакцій підшипникових вузлів у кожному миттєвому осередку деформації, незважаючи на симетричне щодо осі прокатки їх розташування, різні. Як було показано в [5], така особливість взаємодії оброблюваного виробу з полукалібрами обумовлює спотворення миттєвих осередків деформації, що призводить до непрогнозованої змінності геометричних характеристик готового виробу. Якщо жорсткий кінематичний зв'язок функціонування лінії подачі з розвитком процесу взаємодії валків і оброблюваного виробу (практична відсутність розкиду величин подач) стабілізує холоднопільгерний процес, то орієнтація рівнодіючих контактних сил, яка визначається як геометрією полурівчаків, так і особливостями кантування, повинна налаштовуватися стосовно особливостей кожного поточного режиму.

Слід зазначити, що здійснювана в процесі модернізації станів ХПТ заміна росподільноподаючого механізму, (РПМ) комплексом з епіциклічними перетворювачами на базі використання А.с. СРСР № 532413, № 818683, №1409359, вже в 70-х роках минулого століття започатковано процес трансформації агрегату холодного пільгерування в багатодвигунну систему, що забезпечує незалежну реалізацію технологічних операцій ХПТ без втрати їх якісних характеристик у всьому діапазоні робочих темпів (можливість незалежного регулювання величин подачі і повороту без зупинки стану, виключення взаємовпливу особливостей роботи елементів приводу переміщення кліті й ведених ланок ліній подачі і повороту) $[6,7]$.

Застосування в металургійному машинобудуванні серводвигунів, оснащених системами зворотного зв'язку, дозволяє істотно спростити реалізацію операцій періодичних лінійних і кутових переміщень виробу в осередку деформації. Їх висока перевантажувальна здатність відкриває можливість використання в лінії подачі кулько-гвинтової передачі, що забезпечує як реалізацію високоточних переміщень, так і будь-яких режимів підпору. 


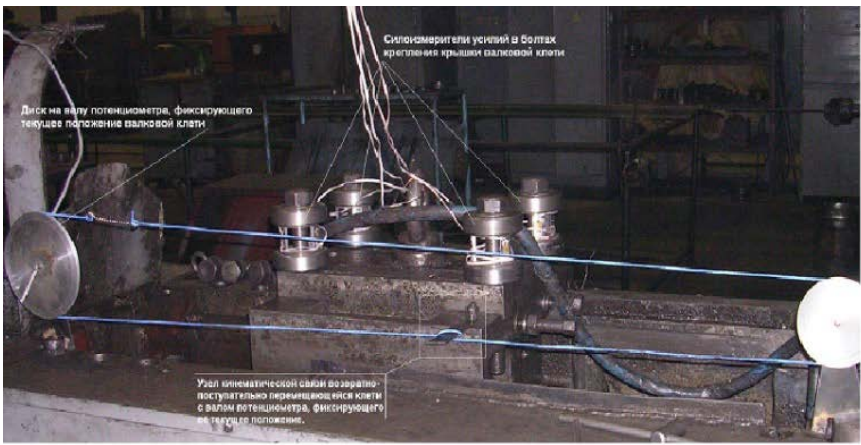

a

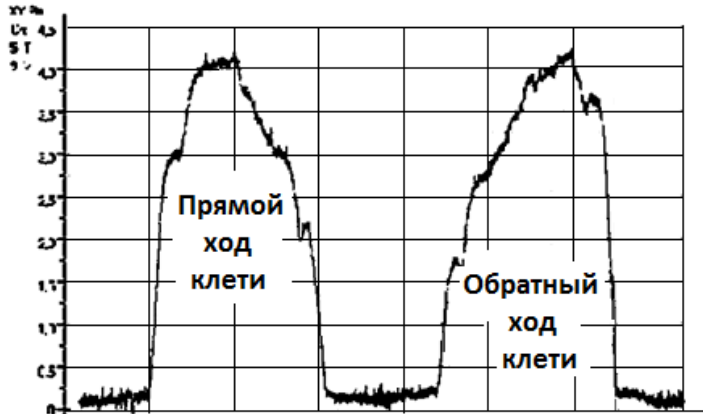

B

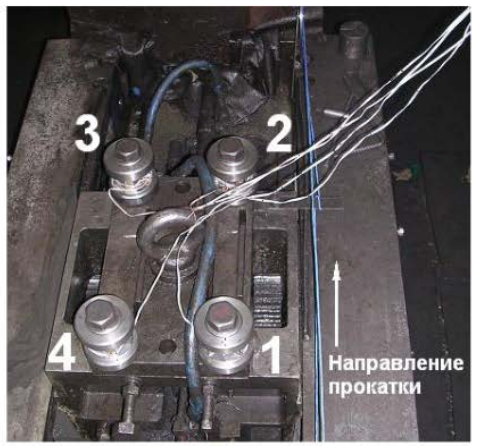

б

Рис. 2. Валкова кліть стану ХПТР 15-30 конструкції ТОВ «НВФ« СХІД ПЛЮС»; (вид збоку $-a$; вид зверху $-\sigma$ ), яка оснащена силовимірювачами, і картини зміни вертикальних складових сили прокатки при виготовленні елементів теплообмінників:

в - зі сталі 0Х18Н10Т за маршрутом $25 \times 1,7 \rightarrow 11,9 \times 1,45(\mu=7,8$ мм, кут повороту $60^{0}$ ); - зі сталі 20 за маршрутом $25 \times 2,5 \rightarrow 11,95 \times 1,45$ (подача 3 мм, кут повороту $60^{0}$ )

Ці можливості були використані при модернізації стану ХПТР 15-30 в умовах ТОВ «МЕДСПЕЦТРУБ», в результаті якої підвищилася його продуктивність як за рахунок підвищення темпів роботи, так і використання раціональних режимів прокатки. На рис. 3 представлені кінематичні схеми, а в таблиці 1 - порівняння основних характеристик стану ХПТР 15-30 до і після модернізації.
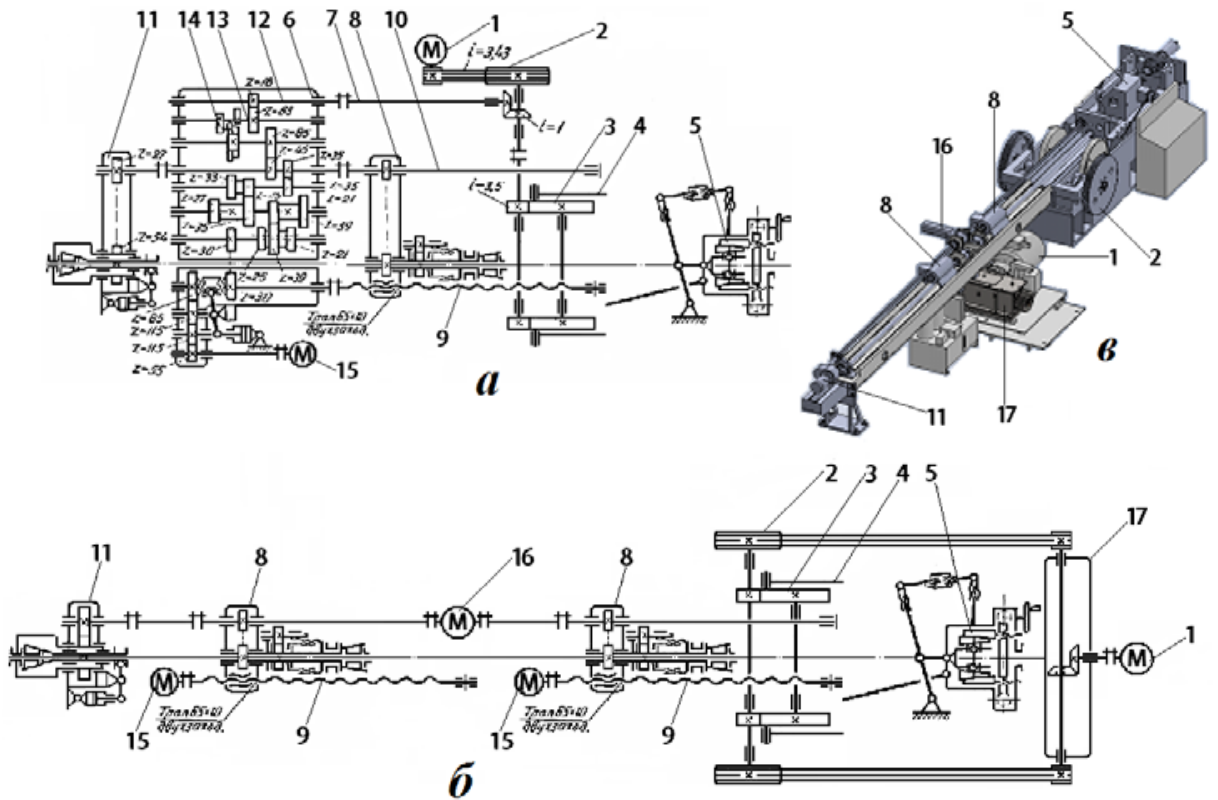

Рис. 3. Кінематичні схеми станів ХПТР 15-30:

( $a$ - розробка ВНІІМЕТМАШ; $\sigma$ - розробка ТОВ «НВФ« СХІД ПЛЮС »; $в$ - реалізація в умовах ТОВ «МЕДСПЕЦТРУБ») 
Порівняльні характеристики станів ХПТР 15-30 разробка ВНДІМЕТМАШ - АЗТМ і модернізованого ТОВ «НВФ« СХІД ПЛЮС »

\begin{tabular}{|c|c|c|c|}
\hline $\begin{array}{l}\text { Порівнянні } \\
\text { показники }\end{array}$ & Найменування показника & Виконання АЗТМ & $\begin{array}{c}\text { Виконання } \\
\text { ТОВ «НВФ« СХІД } \\
\text { ПЛЮС » }\end{array}$ \\
\hline \multirow{3}{*}{$\begin{array}{l}\text { Параметри } \\
\text { заготовки }\end{array}$} & Зовнішній діаметр, мм & $20 \ldots 33$ & $20 \ldots 35$ \\
\hline & Товщина стінки, мм & $0,5 \ldots 4( \pm 6 \%)$ & $0,5 \ldots 4( \pm 6 \%)$ \\
\hline & Довжина, м & $1 \ldots 5$ & $1 \ldots 5$ \\
\hline \multirow{3}{*}{$\begin{array}{l}\text { Параметри готової } \\
\text { труби }\end{array}$} & Зовнішній діаметр, мм & $15 \ldots 30$ & $8 \ldots 30$ \\
\hline & Товщина стінки, мм & $0,3 \ldots 3$ & $0,1 \ldots 4$ \\
\hline & Довжина, м & до 18 & 18 и более \\
\hline \multirow[b]{2}{*}{ Подача } & Величина мм/дв. ход & $\begin{array}{l}1,3 ; 2,1 ; 3,0 ; 4,0 \\
6,4 ; 9,0\end{array}$ & $0 \ldots 20(+5 \%)$ \\
\hline & Спосіб регулювания & $\begin{array}{l}\text { в передньому по- } \\
\text { ложенні кліті, } \\
\text { дискретно з зупи- } \\
\text { нкою стану }\end{array}$ & $\begin{array}{l}\text { плавно без зупинки } \\
\text { стану за заданою } \\
\text { програмою }\end{array}$ \\
\hline \multirow{2}{*}{$\begin{array}{l}\text { Поворот системи } \\
\text { «заготовка- } \\
\text { оправочний } \\
\text { стержень-готова } \\
\text { труба» }\end{array}$} & $\begin{array}{l}\text { Величина кута повороту } \\
\text { в градусах }\end{array}$ & $39,60,90$ & $0 \ldots 240(+5 \%)$ \\
\hline & Спосіб регулювання & $\begin{array}{l}\text { в передньому } \\
\text { положенні кліті, } \\
\text { дискретно з зупи- } \\
\text { нкою стану }\end{array}$ & $\begin{array}{l}\text { плавно без зупинки } \\
\text { стану за заданою } \\
\text { програмою }\end{array}$ \\
\hline \multirow[b]{2}{*}{$\begin{array}{l}\text { Привід } \\
\text { переміщення кліті }\end{array}$} & Темп роботи дв. хід / хв. & $61 ; 83 ; 124$ & $0 \ldots 240$ \\
\hline & Спосіб регулювання & $\begin{array}{l}\text { дискретно з зупи- } \\
\text { нкою стану }\end{array}$ & $\begin{array}{l}\text { плавно без зупинки } \\
\text { стану }\end{array}$ \\
\hline
\end{tabular}

В результаті заміни поворотньо-подаючего комплексу з мальтійським хрестом двома незалежними системами механізмів, що реалізують поступальний і обертальні рухи заготовки, оправки і готової труби досягнута зміна металоємкості стану. Установка двох патронів періодичної подачі відкриває можливість подальшої модернізації з метою організації неперервного процесу. Вирішення цього завдання забезпечується подвоєнням механізмів фіксації стрижня оправки і оснащенням стану комплексом, що транспортує заготовку в зону роботи патронів подачі. Схема стану, що реалізує неперервний холоднопільгерний процес, представлена на рис. 4.

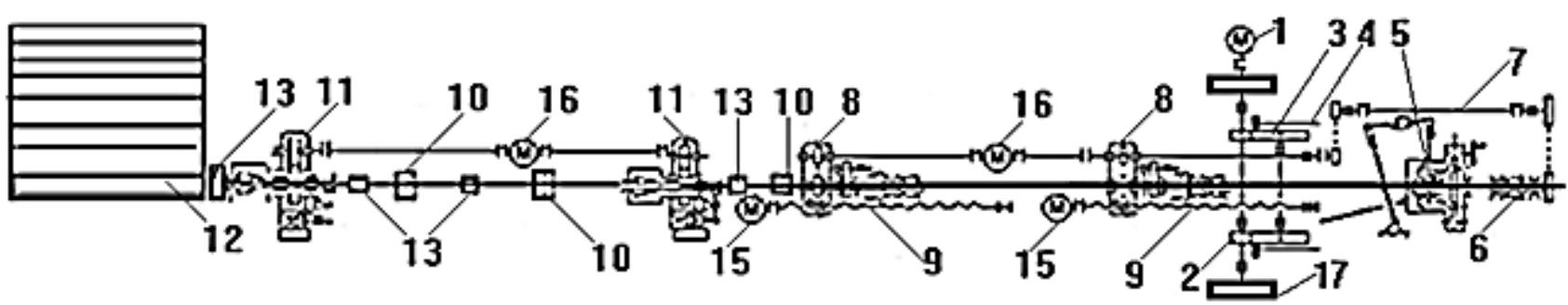

Рис. 4. Схема стану ХПТР 15-30, який забезпечує неперервний процес прокатки трубчастих виробів

Поступаюча на стіл завантаження 12 заготовка транспортуючими пристроями 13 переміщується в зону роботи патронів подачі і повороту 8 , які за допомогою кулько-гвинтових механізмів 9, що приводяться сервоприводами 15 , забезпечують періодичний процес її пода- 
чі в осередок деформації. При цьому величина подачі може бути змінена без зупинки стану. Регульовану зміну кута повороту системи «заготовка - оправка - готова труба» здійснюють сервоприводи 16. Стабільність орієнтації конічної оправки в поздовжньому напрямку (вздовж осі прокатки) забезпечують пристрої 10, які запобігають втраті стійкості стержня її утримання. При виготовленні виробів з немагнітних матеріалів підвищення точності позиціювання конічної оправки може бути досягнуто за рахунок ії оснащення змінним наконічником, що включає сердечник, виконаний з магнітного матеріалу, і розміщується в соленоїді [8].

У порівнянні зі схемою, представленою на рис. 3, б, зазнала зміни і лінія головного приводу, що виразилося в ліквідації пасової передачі руху від двигуна на кривошипні колеса. При цьому валу косозубих зубчастих коліс 2 забезпечена можливість поздовжнього уздовж його осі переміщення [9], що дозволяє нівелювати прояви згубних для протікання холоднопільгерного процесу галопування і нишпорення кліті, що обумовлюються неминучою різницею лінійних розмірів шатунів спареного кривошипно-повзунного механізму. 3 метою зниження таких показників роботи машинного агрегату, як показник нерівномірності його руху і коефіцієнт динамічності, лінія головного приводу включає маховики 17.

Істотним є розчленування складної механічної системи стану на ряд незалежних силових ланцюгів (лінію головного приводу, лінію подачі і лінію повороту), взаємодія яких здійснюється системою управління зв'язком сервоприводів цих ланцюгів (ліній подачі і повороту) з силовою установкою переміщення рухомої кліті. В результаті цього змінилися динамічні параметри лінії головного приводу стану ХПТР 15-30, що, безсумнівно, позначилося на особливостях іiі роботи.

Для аналізу навантажень, які періодично змінюються за цикл роботи стану ХПТР 15-30, що виникають при різних режимах роботи лінії головного приводу, проведені дослідження найпростішої двохмасової динамічної моделі головного приводу стану ХПТР 15-30, яку описано диференціальними рівняннями:

$$
\left\{\begin{array}{l}
I_{1} \frac{d^{2} \varphi_{1}}{d t^{2}}+c\left(\varphi_{1}-\varphi_{2}\right)=-M_{1} \\
I_{2} \frac{d^{2} \varphi_{2}}{d t^{2}}-c\left(\varphi_{1}-\varphi_{2}\right)=M_{2}
\end{array}\right.
$$

де $M_{1}$ - момент технологічного опору з боку осередка деформації стану;

$M_{2}$ - момент на валу электродвигуна головного приводу стана;

$\varphi_{1}, \varphi_{2}$ - кутові переміщення мас моделі силової лінії стану ХПТР 15-30;

$I_{1}, I_{2}$ - моменти інерції відповідних мас;

c - еквівалентна крутильна жорсткість зв'язків між масами системи.

У процесі формування моделі виконані спрощення, що виразилися в замінених розподілених мас стрижневої системи шатунів приводу робочої кліті дискретними, приєднаними до мас кліті і кривошипного вала; і в нехтуванні їх пружною деформацією.

$$
I_{1}=I+2 I_{m}+m_{1} R^{2}
$$

де $m_{1}$ - маса частини шатунів, що приєднується до кривошипного валу;

I - момент інерції кривошипних коліс;

$I_{m}$ - момент інерції маховика головного приводу стану;

$R-$ радіус кривошипних коліс стану ХПТР 15-30.

В рамках даної двухмассовой динамічної моделі головного приводу стану ХПТР 15-30 періодично змінюється приведений момент інерції системи «робоча кліть-шатуникривошипні колеса», який з урахуванням вищевикладеного визначається у вигляді: 


$$
\bar{I}_{1}=I+2 I_{m}+m_{1} R^{2}+\frac{1}{2} m_{2} R^{2}(1-\cos (2 \omega t)),
$$

де $m_{2}$ - загальна маса рухомої частини робочої кліті і відповідної приєднаної маси шатунів;

$\omega$ - встановлена величина кутової швидкості кривошипного колеса.

Тоді, згідно з $[10,11]$, з системи рівнянь (1) маємо:

$$
\frac{d^{2} M_{12}}{d t^{2}}+\frac{c\left(\bar{I}_{1}+I_{2}\right)}{\bar{I}_{1} I_{2}} M_{12}=c\left(\frac{M_{1}}{I_{2}}+\frac{M_{2}}{\bar{I}_{1}}\right)
$$

де $M_{12}=c \varphi=c\left(\varphi_{1}-\varphi_{2}\right) ; \bar{I}_{1}=I+2 I_{m}+m_{1} R^{2}+\frac{1}{2} m_{2} R^{2}-$ деяке усереднене значення приведеного моменту інерції кривошипних коліс, шатунів і робочої кліті механічної системи стану ХПТР 15-30.

3 рівняння (4) видно, що коефіцієнт при функції залежить строго від часу. Це є характерною відзнакою від випадків, що розглянуті в роботах, виконаних раніше. Відзначимо, що в рамках даної задачі (дослідження динаміки приводу робочої кліті стану ХПТР 15-30) змінність коефіцієнта пов'язана з періодичними змінами моменту інерції системи, а не іiі жорсткості. Для зручності аналізу динамічних явищ в головному приводі стану ХПТР 15-30 виконаємо спрощення рівняння (4). Зважаючи на малість $m_{2} R^{2} / 2 I_{1}$, порівняно з одиницею, допустимо прийняти, що вихідне диференціальне рівняння (4) прийме наступний вигляд:

$$
\frac{d^{2} M_{12}}{d t^{2}}+c\left(\frac{1}{\bar{I}_{1}}+\frac{1}{I_{2}}\right)\left[1-\frac{I_{2} m_{2} R^{2}}{2 \bar{I}_{1}\left(I_{2}+\bar{I}_{1}\right)} \cos (2 \omega t)\right] M_{12}=c \frac{M_{1} I_{2}+M_{2} \bar{I}_{1}}{I_{2} \bar{I}_{1}}
$$

Для дослідження динаміки головного приводу стану ХПТР 15-30 диференціальне рівняння (5) зручно представити у вигляді відомих параметричних рівнянь Матьє-Хілла з характерною правою частиною [11]. Після підстановок параметрів динамічної моделі механічної системи і деяких перетворень рівняння (5) запишемо для прийнятої узагальненої математичної моделі приводу стану ХПТР 15-30, що задовольняє умовам поставленого завдання, у вигляді:

$$
\frac{d^{2} M_{12}}{d t^{2}}+\Omega^{2}[1-\mu \cos (2 \omega t)] M_{12}=c \frac{M_{1} I_{2}+M_{2} \bar{I}_{1}}{I_{2} \bar{I}_{1}}
$$

де $\Omega^{2}=c\left(\frac{1}{I_{2}}+\frac{1}{\bar{I}_{1}}\right)$ - квадрат частоти власних коливань обраної динамічної моделі механічної системи силової лінії стану ХПТР 15-30;

$$
\mu=\frac{I_{2} m_{2} R^{2}}{2 \bar{I}_{1}\left(\bar{I}_{1}+I_{2}\right)}-\text { коефіцієнт збудження двохмасової динамічної моделі силової лінії }
$$
стану ХПТР 15-30.

Коефіцієнт динамічного збудження системи і частота ії вільних коливань визначаються з характерних умов взаємної зміни динамічних параметрів силової лінії стану ХПТР 15-30. 
Рішення диференціального рівняння (6) дозволяє оцінити динамічні переміщення, зображає точки приводу робочої кліті стану ХПТР 15-30 для найбільш поширених форм коливань цієї системи. Момент сил пружності головної силової лінії стану ХПТР 15-30 визначається і носить параметричний характер (рис. 5, а).

Розроблена математична модель силової лінії стану ХПТР 15-30 суттєво уточнює іiї поведінку і досить достовірно описує параметричні явища в приводі робочої кліті стану. Раціональні умови функціонування цієї механічної системи зручно оцінити на базі поширеної діаграми стійкості Айнса - Стретта [11] (ріс. 5, б) яка дозволяє проаналізувати можливі області параметричної стійкості функціонування лінії приводу робочої кліті і може бути використана при виборі оптимальних режимів прокатки труб на стані ХПТР 15-30. Відповідні області динамічної стійкості функціонування приводу стану ХПТР 15-30 виділені заштрихованими зонами діаграми. При використанні діаграми стійкості Айнса-Стретта слід брати до уваги те, що в даному випадку частота зміни коефіцієнта інертності системи дорівнює ні $\omega$, а $2 \omega$. Тому основна область параметричного резонансу елементів приводу відповідає $2 \omega / \Omega=2$, тобто $\omega / \Omega=1$. 3 досвіду експлуатації станів холоднопільгерної прокатки відомо, що при деяких режимах роботи в лініях їх приводів спостерігаються значні параметричні коливання. Можливість моделювання квазігармонічних коливань в головному приводі і вибір оптимальних режимів прокатки високоякісних труб на етапі проектування технологічних процесів істотно відрізняє отримані результати від результатів раніше відомих робіт.

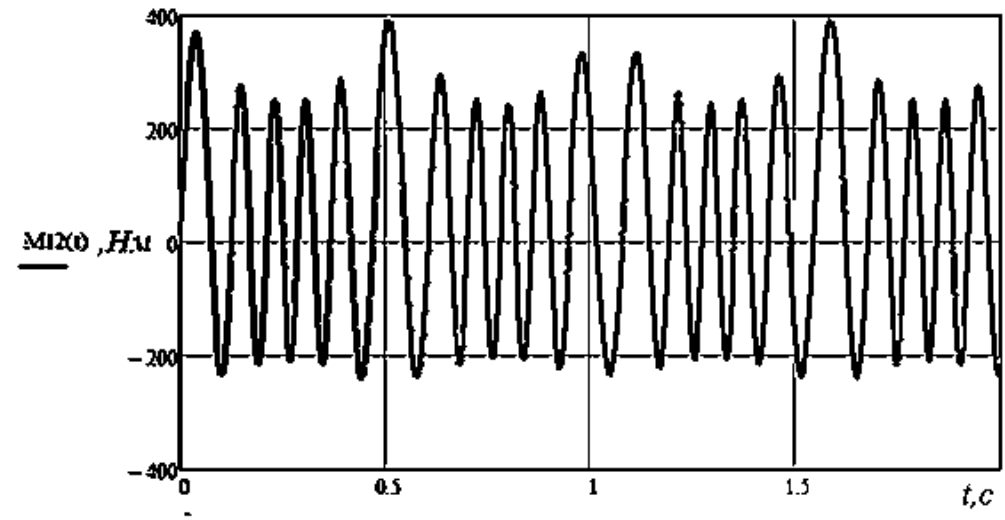

a

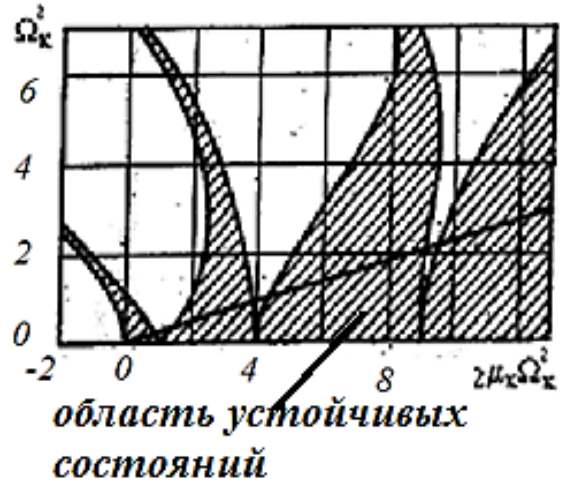

6

Рис. 5. Момент сил пружності зв'язку в головній силовій лінії:

а) узагальнена діаграма; б) параметрична стійкість обраної динамічної моделі силової лінії стану ХПТР 15-30

Підкреслимо деякі особливості формування розрахункових параметрів системи активного управління коливаннями деформувальних систем головної силової лінії стану ХПТР. Вибираємо клас керуючих впливів заздалегідь задавамої структури з урахуванням можливості реалізації самого базового керуючого пристрою і вимог, що пред'являються до технологічного процесу прокатки труби. При цьому, параметри феноменологічної моделі області бажаних станів механічної системи головного приводу стану ХПТР визначаються з умов мінімуму коефіцієнта динамічності або реалізації стійких технологічних режимів у процесі прокатки труб на стані. Параметри керуючих впливів заздалегідь задаваемої структури формуються елементами приводу з різними збуреннями за допомогою автоматизованої системи адаптивного управління. Відзначимо, що вони оптимальні за швидкодією (за час $t=T_{\min }$ ), що дозволяє переводити вихідну механічну систему головного приводу стану ХПТР 15-30 за найкоротший час в область бажаних станів з допустимим рівнем віброактивності системи. На практиці для визначення структури керуючої системи і параметрів раціонального управління найчастіше застосовується полузворотний метод управління коливаннями механічних 
систем, запропонований в роботі [10], який базується на використанні відомих класів і видів реальних виконавчих пристроїв активної системи управління коливаннями механічної системи. Головний привід стану ХПТР 15-30 як механіко-кібернетичний об'єкт повинен бути забезпечений рядом спеціальних пристроїв і систем управління, що дозволяє переводити вихідну механічну систему 3 критичного стану в область бажаних станів. Сутність підходу управління коливаннями деформуемої системи приводу стану ХПТР 15-30 полягає в тому, що в силову лінію стану вводиться додатковий керуючий пристрій, що реалізує силове або кінематичне адаптивне управління заздалегідь певної структури за допомогою сучасного електроприводу (сервоприводу). Очевидно, що розглядаєма задача зводиться до визначення параметрів раціонального впливу керуючої системи на елементи головного приводу. Для вирішення завдань оптимального управління коливаннями аналогічних деформуемих систем, як правило, використовується добре відомий метод (метод варіації параметрів), запропонований в роботах [10-12]. 3 аналізу отриманих результатів випливає, що якісно змінюються динамічні процеси в лінії приводу і механічна система силової лінії стану ХПТР 15-30 може бути переведена в область бажаних станів (допустимих коливань моментів сил пружності), а подальший процес прокатки труби буде відбуватися в стійкому режимі.

Процес активного управління коливаннями лінії головного приводу стану реалізується в такий спосіб. На приводному валу головного приводу стану ХПТР заздалегідь встановлюються датчики порогового значення моментів сил пружності. Під час пружних коливань приводного вала за сигналами датчиків проводиться порівняння з параметрами області бажаних станів механічної системи. Далі відбувається формування відповідного керуючого впливу виконавчого пристрою відомого класу і виду, по закладеним в систему алгоритмам, що стежить за управлінням електроприводу. Коли зображена точка досягає бажаної області динамічної стійкості системи, активне управління приводом відключається. Якщо в процесі прокатки обурючє навантаження, прикладене з боку осередка деформації, виводить динамічні характеристики лінії приводу за рамки області бажаних станів, то процес управління за заданим алгоритмом повторюється в автоматичному режимі. Утримання зображеної точки лінії приводу по сигналу датчика (моменту сил пружності) в процесі прокатки труби в режимі стеження забезпечує стале функціонування елементів лінії приводу. Необхідно підкреслити, що застосування даного способу оптимального управління коливаннями механічної системи пов'язано з використанням адаптованого математичного апарату і спеціальних методів операційного числення.

Розчленування громіздкої механічної системи стану ХПТР 15-30 конструкції ВНІМЕТМАШ-АЗТМ (рис. 3, а) дозволяє більш усвідомлено використовувати відомі прийоми регулювання ходу машин, які зводяться до використання маховиків і так званих врівноважують пристроїв, покликаних забезпечити зниження фактора змінюваних інерційних сил у лініях головних приводів цих машин Так, на початкових етапах вдосконалення лінії головного приводу, що складається 3 електродвигуна, вузлів передачі обертання його ротора на механізм зворотнопоступального руху кліті, задовільними були відомі рішення часткового статичного зрівноважування у вигляді використання ексцентрично розміщених мас на елементах, які роблять обертальний рух (рис. 6, a).

Подальший розвиток представлено застосуванням в якості механізму зворотнопоступального руху кліті V-образного кривошипно-ползунного механізму із загальним кривошипом і віддаленими на 90 градусів лініями руху основного (робоча кліть $\mathrm{m}_{1}$-горизонтально) i додаткових (врівноважуючи маси - контрвантажі $\mathrm{m}_{3}$ - вертикально) ползунів (рис. 6, б).

Єдино можливий варіант повного статичного зрівноважування приводу зворотнопоступального руху кліті, який використовується на станах малих типорозмірів, виконаний за схемою Латіра (рис. 6, в), реалізований розміщенням на кривошипах і шатунах, вирішуючих завдання, урівноважувальних вантажів. 


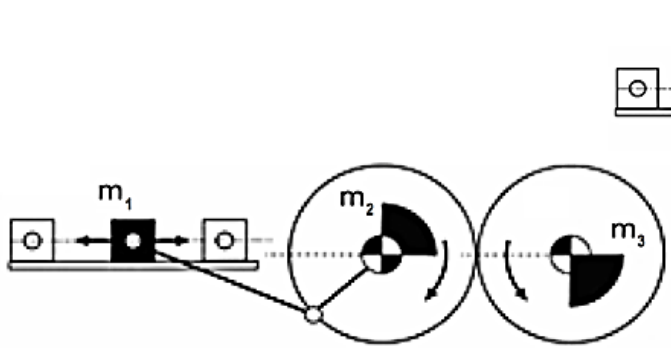

a

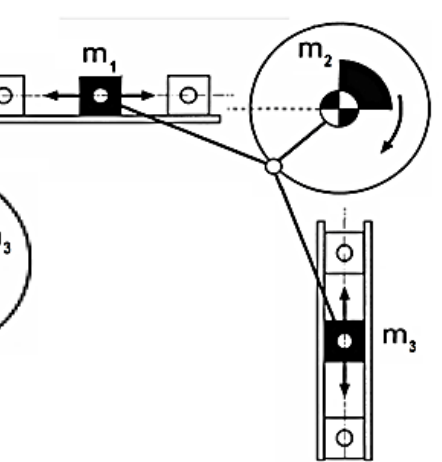

б

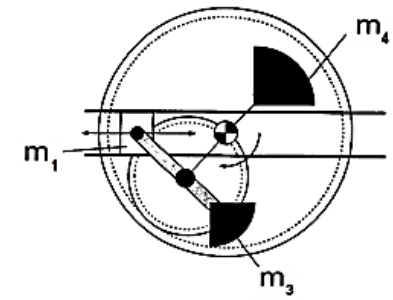

B

Рис. 6. Класичні методи урівноважування, реалізовані в конструктивних рішеннях приводу переміщення кліті холоднопільгерних станів фірми Маннесманн - Меєр

Використовані фірмою Маннесманн-Меєр рішення дозволивши вирішувати завдання зниження впливу фактора інерційних сил на нерівномірність ходу машинного агрегату (вирівнювання моменту на валу електродвигуна), забезпечили підвищення темпу роботи станів. Однак цим конструктивним пропозиціям притаманний такий недолік як істотне збільшення матеріаломісткості агрегату - величини мас, що забезпечують часткове або повне урівноваження, перевищуючи масу рухомий кліті. Витратна складова цим не обмежується. Так, у разі застосування вантажного врівноважуючого пристрою на стані КПГ 41 /2" потрібно значне (більш ніж на 5,5 м) заглиблення фундаменту, що обумовлює підвищення вартості об'єкта. Крім того вантажне урівноваження не усуває динамічних навантажень діючих в таких важко навантажених вузлах приводного механізму, як з'єднання шатунів з робочою кліттю і кривошипним валом.

В результаті аналізу способів вирівнювання навантажень на приводному валу та вирішуючи завдання урівноваження сил інерції поступально переміщающихся мас головного приводу станів ХПТ, а також прагнення розвантажити вузли кінематичних з'єднань, призвело до створення приєднуемих безпосередньо до робочої кліті пристроїв програмного урівноваження, в яких акумулювання і віддача енергії реалізується пневматичними навантажувачами [13]. Так, Електростальскій завод важкого машинобудування (ЕЗТМ) обладнав стани ХПТ третьої моделі поршневими пневмонавантажувачами 3 політропічним процесом стиснення повітря. Сістема управління (зміни тиску газу в порожнинах циліндра) представлена дозволяє не тільки регулювати ступінь врівноваження сил інерції кліті при змінюваних темпах роботи стану, а й здійснювати «переуравноваження» - часткове нівелювання технологічного навантаження.

Усунення динамічних навантажень, діючих у важко навантажених вузлах з'єднання шатунів з робочою кліттю і кривошипним валом, досягається також реалізацією рішення, представленого на рис. 7.

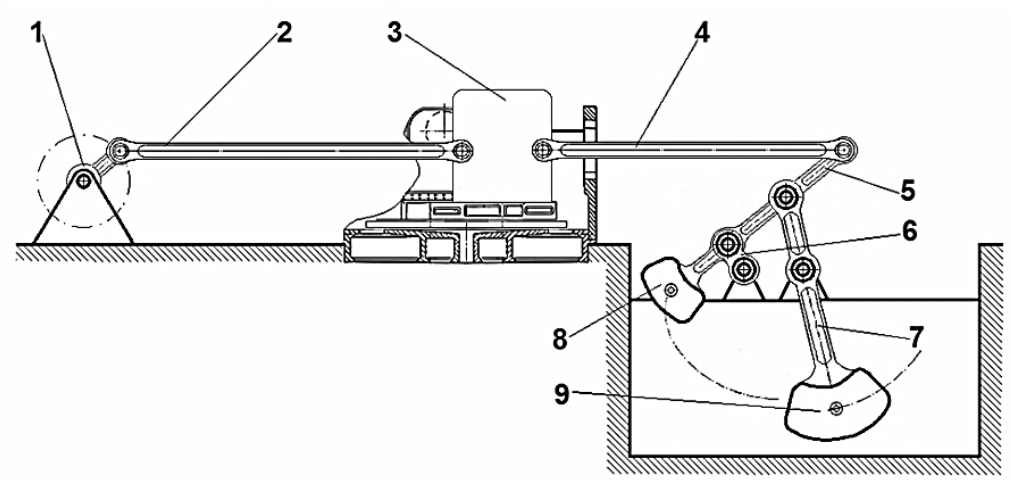

Рис. 7. Привід переміщення кліті стану холодної пільгерної прокатки труб [14] 
Процес врівноваження сили інерції мас кліті 3 і шатунів 2 спареного кривошипноповзунного механізму реалізується в результаті взаємодії з силами інерції балансирного вантажу 9 і врівноважуючего вантажу 8 вирішення завдання для табору ХПТР.

\section{ВИСНОВКИ}

Показано, що виготовлення конкурентоспроможної продукції може бути забезпечене не тільки за рахунок придбання нового обладнання (станів нового покоління), але і менш витратною модернізацією існуючих станів ХПТР 15-30 при збереженні не вичерпавших свій ресурс базових деталей.

Складені диференціальні рівняння руху і наведені дослідження динаміки двухмассовой моделі стану ХПТР15-30. Встановлені активні механічні зв'язки в вихідній динамічній моделі, які обумовлюють прояв яскраво виражених параметричних процесів в досліджуваній механічній системі.

Виявлено основні причини виникнення параметричних коливань в головній силовій лінії стану ХПТР15-30 і визначені зони динамічної нестійкості функціонування механічної системи, що дозволяє здійснити вибір пасивних оптимальних режимів холодної прокатки труб на етапі проектування технологічних процесів.

Обрана структура оптимального управління кутовими коливаннями елементів силової лінії стану ХПТР15-30, як механіко-кібернетичною системою. На базі розробленої математичної моделі запропонована система активного управління головним приводом стану ХПТР15-30.

Запропоновано механізм реалізації оптимального управління динамічним станом елементів лінії приводу стану ХПТР15-30. Підтверджено достовірність отриманих результатів і доцільність прийнятих технічних рішень.

Наведені приклади конструктивних рішень пристроїв зрівноважування мас механічної системи, використання яких не тільки підвищить термін служби елементів лінії головного приводу, але і забезпечить зростання продуктивності за рахунок зміни темпів роботи станів і зміни якісних характеристик продукції, що виготовляється.

\section{СПИСОК ВИКОРИСТАНОЇ ЛІТЕРАТУРИ}

1. Боровик А. А. Многодвигательный электропривод стана холодной прокатки труб. Электротехника. 2010. 3. С. 20-25.

2. Усынин Ю. С., Остроухов В. В. Применение индивидуального электропривода в механизмах подачи станов холодной прокатки труб. Научно-технические ведомости СПб ГПУ. Наука и образование. СанктПетербург: Изд-во СПб ГПУ, 2010. 4(110). С. 96-100.

3. Усынин Ю. С., Остроухов В. В. Оптимизация быстродействия электропривода подачи стана холодной прокатки труб. Наука ЮУрГУ: материаль 62-й науч. конф. Секиии техн. науки. Челябинск: ЮУрГУ, 2010.2. C. 205-208.

4. Остроухов В. В. Исследование электропривода подачи стана холодной прокатки труб как объекта автоматизации. Материалы третьей научной конференции аспирантов и докторантов. Технические науки. Челябинск: ЮУрГУ. 2011. С. 136-140.

5. Вышинский В. Т. Влияние на выходные параметры изделий кинематических и силовых особенностей формирования очага деформации при холодной пилигримовой прокатке. Теория и практика металлургии. 2000.5. C. 25-26.

6. Вышинский В. Т., Данченко В. Н., Рахманов С. Р., Фролов Я. В. Анализ подходов к созданию станов холодной прокатки труб. Пластична деформація металів. Колективна монографія. ТОВ «Акцент ПП». 2014. C. 218-235.

7. Вышинский В. Т. Анализ возможностей управления холодной прокаткой труб. Обработка материалов давлением: Краматорск: ДГМА. 2016.1 (42). С. 242-249.

8. Пат. Україна 120976. В21В 21/00. Пристрій для встановлення оправки в стані холодної прокатки труб. Вишинський В. Т., Рахманов С. Р. 2020

9. Пат. Україна 104223. В21B 21/00. Привідний механізм стану холодної прокатки труб. Вишинський В. Т., Рахманов С. Р., Поворотній В. В. 2016.

10. Карновский И. А., Почтман Ю. М. Оптимальное управление колебаниями деформируемых систем. Киев: Вища школа, 1985. 254 с. 
11. Пановко Я. Г. Основы прикладной теории упругих колебаний. Москва: ГНТИ, 1957. 546 с. $1975.568 \mathrm{c}$

12. Бутковский А. Г. Методы управления системами с распределенными параметрами. Москва: Наука,

13. Кожевников С. Н., Климковский Б. М., Ткаченко А. С. Способы выравнивания нагрузок на приводном валу и уравновешивание сил инерции возвратно-поступательно перемещающихся масс главного привода станов ХПТ. Модернизация и автоматизация металлургического оборудования. Труды Днепропетр. ИЧМ. Москва: Металлургия, 1965. 20. С. 76-93.

14. Пат. Україна 120986. В21В 21/00. Привідний механізм стану холодної прокатки труб. Вишинський В. Т., Рахманов С. Р. 2020.

\section{REFERENCES}

1. Borovik A.A. Multi-motor electric drive of the pipe cold rolling mill. Electrical Engineering Magazine, 2010. 3, pp. 20-25. (in Russian).

2. Usynin Yu.S., Ostroukhov V.V. The use of an individual electric drive in the feed mechanisms of cold pipe rolling mills. Scientific and technical statements of SPbSPU. Science and education. Publishing house of the Polytechnic University, 2010. 4 (110), pp. 96-100. (in Russian).

3. Usynin Yu.S., Ostroukhov V.V. Optimization of the speed of the electric drive of the cold-rolling mill feed. Science of SUSU: Materials of the 62th scientific. conf. Technical sections sciences. Chelyabinsk. 2010. 2, pp. $205-208$. (in Russian).

4. Ostroukhov V.V. Investigation of the electric drive of the cold-rolling mill feed as an automation object. Scientific search: Materials of the 3th scientific conference of graduate and doctoral students. Technical science. Chelyabinsk: SUSU Publishing Center. 2011, pp. 136-140. (in Russian).

5. Vyshinsky V.T. Influence of the kinematic and force features of the deformation zone formation during cold pilgrim rolling on the output parameters of products. Theory and practice of metallurgy. 2000.5, pp. 25-26. (in Russian).

6. Vyshinsky V.T., Danchenko V.N., Rakhmanov S.R., Frolov Ya.V. Analysis of approaches to the creation of cold pipe rolling mills. Plastic deformation of metals. Collective monograph. Ltd. “Accent PP”. 2014, pp. 218-235. (in Russian).

7. Vyshinsky V.T. Analysis of the possibilities of controlling the cold rolling of pipes. Materials Working by Pressure. Kramatorsk: DSEA, 2016. 1 (42), pp. 242-249. (in Russian).

8. Pat. 120976 Ukraine. B21B 21/00. Pristiy for setting the mandrel in the cold rolling mill. Vishinsky V.T., Rakhmanov S.R. 2020.

9. Pat. 104223 Ukraine. B21B 21/00. Private mechanism for cold rolling of pipes. Vishinsky V.T., Rakhmanov S.R., Povorotniy V.V. 2016. (in Russian)

10. Karnovsky I.A., Pochtman Yu.M. Optimal control of oscillations of deformable systems. Kyiv. 1985. 254 p.

11. Panovko. Ya.G. Foundations of the applied theory of elastic vibrations. Moscow. GNTI. 1957. 546 p.

12. Butkovsky A.G. Methods for managing systems with distributed parameters. Moscow: Science. 1975. 568 p.

13. Kozhevnikov S.N., Klimkovsky B.M., Tkachenko A.S. Methods for balancing loads on the drive shaft and balancing the inertia forces of the reciprocating masses of the main drive of the KhPT mills. Modernization and automation of metallurgist's equipment. Dnepropetrovsk Institute of Ferrous Metallurgy. Moscow: Metallurgy. 1965. 20, pp.76-93. (in Russian).

14. Pat. 120986 Ukraine. B21B 21/00. Private Mechanism of Cold Rolling Mill. Vishinsky V.T., Rakhmanov S.R. 2020.

Вишинський В. Т. - канд. техн. наук, доцент НМетАУ;

Рахманов С. Р. - - директор НПФ «Восток Плюс».

НМетАУ - Національна металургійна академія України, м. Дніпро.

НПФ «Восток Плюс» - Науково-виробнича фирма «Восток Плюс» м. Дніпро.

E-mail: npfvostokplus@gmail.com 